\title{
GIVING WITH ONE HAND AND TAKING AWAY WITH THE OTHER ${ }^{\circ}$
}

\author{
DANDO COM UM MÃO E TIRANDO COM A OUTRA
}

\author{
Carlândia Brito Santos Fernandes* \\ Marina Silva da Cunha* \\ Marcos Roberto Vasconcelos*
}

enviado: 2 octubre 2018 - aceptado: 08 abril 2019

\begin{abstract}
This study analyzes the impact of fiscal policy on income inequality for the Brazilian states over the period 2004-2014. Using the GMM system, we find robust evidence that, while increases in total expenditure, spending with social assistance and security, and expenditure on infrastructure reduce inequality, total and capital revenues and expenditures related to public debt increase inequality. Thus, the net effect of fiscal policy on inequality may not be positive mainly because the tax system is still very regressive and many of the resources are spent on debt. Therefore, the discussion of how to determine and qualify social spending levels in Brazil, which are necessary to fight poverty and reduce social and income inequalities, is directly related to the revision of the tax collection system.
\end{abstract}

Keywords: fiscal policy, public spending, inequality, Brazilian states. JEL codes: O10, O15, E62.

Fernandes, C.B.S, Cunha, M.S, \& Vasconcelos, M. R. (2019). Giving with one hand and taking away with the other. Estudios económicos, 36 (73), 43-70.

* State University of Maringá (UEM), Brazil. E-mail: carlandia@gmail.com,mscunha@uem.br, mrvasconcelos@uem.br. Carlândia Fernandes gratefully acknowledges research funding granted by National Postdoctoral Program (PNPD, as per its initials in Portuguese) of the Coordination for the Improvement of Higher Education Personnel (CAPES, as per its initials in Portuguese). 


\section{Resumo}

Este estudo analisa o impacto da política fiscal sobre a desigualdade de renda para os estados brasileiros no período 2004-2014. Utilizando system GMM, encontramos evidências robustas de que, enquanto o aumento no gasto total, gastos com assistência social e segurança, e gastos em infra-estrutura reduzem a desigualdade, as receitas totais e de capital e os gastos relacionados à dívida pública aumentam a desigualdade. Assim, o efeito líquido da política fiscal sobre a desigualdade pode não ser positivo, principalmente porque o sistema tributário ainda é muito regressivo e muitos dos recursos são gastos em dívidas. Portanto, a discussão sobre como determinar e qualificar os níveis de gastos sociais no Brasil, necessários para combater a pobreza e reduzir as desigualdades sociais e de renda, está diretamente relacionada à revisão do sistema de arrecadação de impostos.

Palavras chave: política fiscal, gasto público, desigualdade, estados brasileiros. Códigos JEL: O10, O15, E62. 


\section{INTRODUCTION}

The question of inequality has assumed a prominent place in debates on economic policy, especially following the global financial crisis and the academic and political repercussions of Piketty's book (2014). This debate has drawn attention to the capacity and importance that fiscal policy may have in mitigating income imbalances among individuals in an economy.

Fiscal policy can affect the welfare of individuals through direct monetary payments or through government provision of free services. In other words, fiscal policy can have an immediate impact on income distribution, for example, with benefit payments or tax rates on current income, or it can have effects only in the medium or long terms, such as expenses in child education. In turn, it is important not to forget that the distributive role of fiscal policy can produce negative externalities since some tax and spending policies used for this purpose can distort incentives and reduce economic efficiency (Clements et al., 2015).

In this context, the main objective of this study is to empirically estimate the impact of the structure of expenditures and revenues on income inequality for the Brazilian states. That is, what is the impact of fiscal policy on the inequality of the Brazilian states? What types of expenditure and revenues contribute to the reduction of inequality? Moreover, is it possible that the reductive effect on income inequality obtained since the beginning of the 2000s and resulted from programs that target income transfers at poor households, has been partially softened by the Brazilian regressive fiscal structure?

The contribution of this article is to provide evidence of the relationship between fiscal policy, examining simultaneously tax and public spending, and income inequality at the level of the Brazilian states, filling an existing gap in the literature. In addition, this research provides justifications for policy makers to implement fiscal policies, here considered as public expenditure and tax structures, that promote to the reduction of income inequality in the country. Programs that target income transfers at poor households are important to reduce inequality in income distribution, but their effects can be offset if the tax collection structure is not directed at the distributive goal. Lastly, it should be emphasized that analyzing the issues of allocative efficiency in the expenditure policies of the Brazilian states is not within the scope of the present study, even though the authors recognize the relevance of such an issue.

The remainder of the paper is structured as follows. Section II is a literature review. Section III summarizes the evolution of the intergovernmental fis- 
cal structure in Brazil. Section IV includes the data and methodology. Section V provides the main results. Section VI shows the robustness evaluations. The paper ends with some concluding remarks.

\section{TAXES, PUBLIC EXPENDITURE AND INCOME DISTRIBUTION: A REVIEW OF THE LITERATURE}

Although Kuznet's (1955) hypothesis of an inverted U-curve in the relationship between economic growth and income distribution remains controversial, enthusiasm for this hypothesis has been decreasing since the study by Deininger and Squire (1996). This decreased enthusiasm has made room in recent decades for the argument that the level of income inequality, especially in developing countries, can be reduced by the direct action of public policies, especially fiscal policies (TANZI, CHU, 1992). However, according to Martínez-Vázquez et al. (2012), it is important to evaluate the design of these policies to determine their success in reducing income inequality and benefiting the poorest populations.

Analyses of the relationship between economic development, inequality in income distribution and fiscal policy are found, among others, in Bastagli et al. (2012), Chu et al. (2004) and Woo et al. (2013). The conclusion of these studies is that inequality in income distribution can be partially explained by the level and progressiveness of taxes and government spending policies. These studies also note that, in general, direct taxes and social spending tend to improve the income distribution of the economy, while indirect taxes tend to increase inequality. In addition, the results of Woo et al. (2013) indicate that fiscal policy may favor the long-term trends of both inequality and growth by promoting education and training among low-and middle-income workers. This conclusion is in line with the evidence presented by Martínez-Vázquez et al. (2012) for 150 countries, which detected the occurrence of an increase in income inequality in the period from 1970 to 2009 and a fall in the share of income tax in total tax collection and spending on education.

Highlighting the negative effects of poor income distribution on economic growth in Latin American countries and using data from the beginning of the 2000 decade, Goñi et al. (2011) concluded that the fiscal system of these countries fails to fulfill its redistributive function ${ }^{1}$. However, from the second decade of the 21 st

1 The development of most Latin American countries was characterized by persistent problems related to income inequality throughout the 20th century, as presented in Bértola and Ocampo (2012). However, some studies indicate that in the last two decades, inequality in income distribution has 
century, several studies have emerged showing the positive role of the fiscal system in improving the income distribution in the countries of this region. Cornia (2014) found evidence that, as of 2002, taxes and social spending, among other variables, are significant factors for the improvement of the income distribution in the countries of Latin America. González and Martner (2012) also identified a positive effect of fiscal policy on income distribution, particularly for social spending, expenditure on education, public investment, and an indicator of the progressiveness of the tax system. In a more recent study, Clifton et al. (2017) argued that during the 19601998 period, fiscal policy was not a relevant explanatory factor for the reduction in inequality in income distribution in Latin America. Nevertheless, for the 19902012 period, the authors concluded that fiscal policy contributed to the reduction of inequality in income distribution, mainly via public spending on health and taxes that act progressively on income.

Several studies on South American countries have analyzed in more detail the impact of taxes and expenditures, together or separately, on income distribution. Here, we present some of those studies that perform a joint analysis of expenses and taxes. Bucheli et al. (2014) showed that Uruguay has a tax system that, in terms of both expenses and taxes, is favorable to the distributive function of the State. Although indirect taxes are regressive, the progressiveness of direct taxation more than compensates for this effect, making the Uruguayan tax structure an equalizing element on income in the country. With respect to expenditure, due to the weight of expenditures related to health and education and due to direct income transfers to the poorest segments of the population, the progressiveness of Uruguay's tax system has deepened.

Another country in the region that seems to have a tax system with a distributive character is Argentina. Rossignolo (2018), using data for the year 2012, concluded that both the net effect of direct and indirect expenditures and taxes help reduce income disparity and poverty in Argentina, even with the regressivity of indirect taxation. He also pointed out that the progressive character of the Argentine tax system has been reinforced since the beginning of the year 2000 .

This evolution is proven in an ingenious work by Cont and Porto (2016). These authors used data on household income and fiscal policy in Argentina for the period from 1995 to 2010 to estimate the income distribution produced by market forces (ex-ante income); one estimation results from adding public cash transfers

declined in most of its countries, although Latin America still presents indexes above the world average (Cornia, 2014). 
and subtracting direct taxes (interim income), and another estimation results from adding in-kind public goods and subtracting indirect taxes (ex-post income). From these estimates, the authors calculated the Gini indexes and measured the impact of different types of public expenditure and taxes, both related to the central government and the provinces. The estimated data indicate that fiscal policy in Argentina has been able to increase its capacity to reduce income disparity among families, mainly through the expenses of the governments of the provinces and those related to direct cash transfers for lower-income families.

Another country that seems to have evolved in the progressiveness of its tax system throughout the first decade of the 21 st century is Peru. According to Jaramillo (2017), by observing the evolution of the Peruvian government's spending and collection structure between 2005 and 2011, it is possible to infer an improvement in the levels of progressivity of expenditures, thanks mainly to the adoption of direct income transfer programs and of direct taxes. However, the regressivity of indirect taxes keeps the system on the revenue side neutral. In addition, the volume of resources and coverage of income transfer programs are still relatively small to contribute substantially to poverty reduction and income inequality in the country. Similar results are found for Colombia, according to Joumard and Vélez (2013). These authors emphasized the low level of tax burden in the country, its concentration on indirect taxes, the low progressivity in income tax, the small coverage of income transfer programs and the regressivity in the social security system as explanatory factors for the reduced distributive role of the Colombian tax system.

Using data for the year 2013 Martinez-Aguilar et al. (2016) showed how Chile, since the beginning of the 21st century, has been creating various government programs and actions that have succeeded in making its tax structure more equal and favorable to the poorest sections of the population. Through estimates of the state's tax and spending impacts, the authors indicated that both direct and indirect taxes and expenditures help reduce income differentials and alleviate the extent and depth of poverty in the country. The efficiency of direct transfer programs, such as income supplementation programs, with their equivalent cost of $1.6 \%$ of the GDP, produced a reduction of $5.4 \%$ in the Gini index.

Higgins and Perreira (2014) evaluated the distributive effects of fiscal policy in Brazil for the years 2008 and 2009. Although these authors underlined the progressive aspects of social policies in the country, especially those of direct income transfer such as the Bolsa Família Program, they concluded that the consolidated effect of fiscal policy was regressive and unfavorable to the poorest segment of the population. This conclusion is mainly due to the large weight of indirect taxes in 
the tax collection system, approximately $55 \%$, and the impact of such taxes on the price of the typical consumer basket of lower-income families. Medeiros and Souza (2015) were even more forceful in assessing the unfavorable role of Brazilian fiscal policy in the distribution of income. Evaluating only the direct monetary flows between families and the public sector, thus without considering the impact of indirect taxes, they concluded that (mostly through the public sector workers' earnings and pensions) the Brazilian State contributes heavily to raising the Gini index in the country, being unable to impose direct taxation to counterbalance this effect. In fact, as Gobetti and Orair (2017) noted, the main direct tax in Brazil, the income tax, has a lower progressivity index than those observed in Argentina, Chile and Uruguay, and it is well below the average estimated for OECD member countries.

Although Cont and Porto (2016) have found evidence that the expenditures of subnational units (provinces) in Argentina are the main determinants of fiscal policy progressivity, there is no consensus in the literature on the impact of fiscal decentralization on income disparity. Bartolini et al. (2016) showed that for a positive impact of fiscal decentralization to on the less developed subnational units local governments must be able to increase their own tax base, specially through public policies capable of attracting new factors and productive resources for the region or or using local resources more efficiently. In short, the effective relationship between fiscal decentralization and income inequality is an empirical question.

\section{EVOLUTION OF THE INTERGOVERNMENTAL FISCAL STRUCTURE IN BRAZIL}

The implementation of a new federal constitution, in 1988, in an already democratic regime, gave greater autonomy, especially to the states, in fiscal management. Based on Public Choice Theory, the expectation was that fiscal decentralization would enable a greater linkage between tax decisions, especially spending decisions, and the preferences and needs of the local population, as formulated by Oates (1972). Likewise, in the political sphere, the idea was to promote the socalled "horizontal distribution", directing more resources from the federal government to the states, especially the less developed ones.

However, without proper mechanisms of transparency, control and accountability of public managers, this autonomy was configured in subnational units, mainly states, with increasing fiscal deficits and levels of public debt. This situation forced the country to promote institutional advances in terms of public finance management at all levels of the federation throughout the second half of the 1990s, beginning 
with the Program for Support of Restructuring and Fiscal Adjustment of States and culminating in the promulgation of the Fiscal Responsibility Law in 2000. Among the highlights of this law was the legal definition that any new expenditure can only be created in the public budget when it has a proper provision for revenue.

These reforms established a new phase in the Brazilian tax administration at all federal levels. From an eminently qualitative perspective, the subnational entities lost their autonomy in the decisions of indebtedness, including being forbidden to issue bonds of public debt. The contracting of financing operations by state governments was under the control of the federal government. Thus, with no capacity to contract new debt, subnational entities began to make efforts to broaden their tax bases and improve institutional capacity for public management. This situation has been partially reversed as of 2009 , when the federal government sought to minimize the effects of the international crisis on the Brazilian economy, once again allowing states and municipalities to contract new financing to increase their investment capacity and thus helping stimulate aggregate domestic demand. These actions softened the impact of the international crisis in Brazil in 2008, 2009 and 2010. However, they withdrew from both the federal and state governments the ability to undertake countercyclical fiscal policies in the recession period from 2014 to 2017.

\section{II.1. The federal units of Brazil}

With a territorial area of 8.5 million $\mathrm{km} 2$ and an estimated population of 214 million in 2018, Brazil comprises 27 subnational units, the objects of our analysis, which have relative political and economic autonomy. As indicated in Table 1, these units present significant differences in terms of territory population, economic size and quality of life. These disparities are also reflected in the fiscal indicators.

Table 1. Regional disparities in socioeconomic indicators by Federal Units

\begin{tabular}{|c|c|c|c|c|c|c|c|c|c|c|}
\hline \multirow{2}{*}{ FU } & \multicolumn{2}{|l|}{ Gini } & \multicolumn{2}{|l|}{ DL } & \multirow{2}{*}{$\begin{array}{l}\text { GDP } \\
\mathrm{pc}\end{array}$} & \multirow{2}{*}{ Area } & \multirow{2}{*}{ Pop } & \multirow{2}{*}{ HID } & \multirow{2}{*}{ Prog } & \multirow{2}{*}{ ICMS } \\
\hline & 2004 & 2014 & 2004 & 2014 & & & & & & \\
\hline $\mathrm{AC}$ & 0.59 & 0.54 & 0.62 & 0.74 & 15629 & 164.1 & 734 & 0.663 & 0.29 & 0.21 \\
\hline $\mathrm{AL}$ & 0.57 & 0.50 & 2.64 & 1.54 & 11218 & 27.8 & 3120 & 0.631 & 0.16 & 0.49 \\
\hline $\mathrm{AM}$ & 0.54 & 0.53 & 0.45 & 0.31 & 18560 & 1559.1 & 3484 & 0.674 & 0.10 & 0.71 \\
\hline AP & 0.54 & 0.47 & 0.23 & 0.41 & 16476 & 142.8 & 670 & 0.708 & 0.17 & 0.21 \\
\hline
\end{tabular}




\begin{tabular}{|c|c|c|c|c|c|c|c|c|c|c|}
\hline BA & 0.56 & 0.53 & 1.42 & 0.4 & 12970 & 564.7 & 14017 & 0.660 & 0.12 & 0.68 \\
\hline $\mathrm{CE}$ & 0.58 & 0.51 & 0.92 & 0.42 & 12527 & 148.9 & 8452 & 0.682 & 0.15 & 0.66 \\
\hline DF & 0.63 & 0.58 & 0.28 & 0.21 & 60020 & 5.8 & 2570 & 0.824 & 0.52 & 0.40 \\
\hline ES & 0.55 & 0.49 & 0.73 & 0.27 & 28263 & 46.1 & 3515 & 0.740 & 0.12 & 0.77 \\
\hline GO & 0.54 & 0.45 & 2.21 & 0.9 & 22467 & 340.1 & 6004 & 0.735 & 0.15 & 0.80 \\
\hline MA & 0.61 & 0.53 & 1.74 & 0.46 & 10008 & 331.9 & 6575 & 0.639 & 0.16 & 0.46 \\
\hline $\mathrm{MG}$ & 0.54 & 0.48 & 2.24 & 1.79 & 21903 & 586.5 & 19597 & 0.731 & 0.19 & 0.80 \\
\hline MS & 0.54 & 0.49 & 2.33 & 0.98 & 26863 & 357.1 & 2449 & 0.729 & 0.14 & 0.91 \\
\hline MT & 0.53 & 0.46 & 1.3 & 0.42 & 28164 & 903.2 & 3035 & 0.725 & 0.14 & 0.74 \\
\hline PA & 0.54 & 0.49 & 0.6 & 0.1 & 13995 & 1248.0 & 7581 & 0.646 & 0.15 & 0.60 \\
\hline PB & 0.59 & 0.51 & 1.08 & 0.37 & 11916 & 56.5 & 3767 & 0.658 & 0.14 & 0.59 \\
\hline PE & 0.61 & 0.51 & 1.04 & 0.58 & 14369 & 98.1 & 8796 & 0.673 & 0.13 & 0.69 \\
\hline PI & 0.59 & 0.50 & 1.42 & 0.61 & 10665 & 251.6 & 3110 & 0.646 & 0.16 & 0.48 \\
\hline PR & 0.55 & 0.45 & 1.08 & 0.58 & 27171 & 199.3 & 10445 & 0.749 & 0.19 & 0.81 \\
\hline RJ & 0.55 & 0.52 & 2.04 & 1.78 & 35194 & 43.8 & 15990 & 0.761 & 0.17 & 0.69 \\
\hline $\mathrm{RN}$ & 0.57 & 0.50 & 0.38 & 0.16 & 14151 & 52.8 & 3168 & 0.684 & 0.17 & 0.56 \\
\hline RO & 0.52 & 0.47 & 1.03 & 0.62 & 17372 & 237.8 & 1562 & 0.690 & 0.14 & 0.55 \\
\hline $\mathrm{RR}$ & 0.58 & 0.50 & 0.04 & 0.18 & 18096 & 224.3 & 450 & 0.707 & 0.24 & 0.22 \\
\hline $\mathrm{RS}$ & 0.53 & 0.48 & 2.83 & 2.09 & 27654 & 281.7 & 10694 & 0.746 & 0.16 & 0.90 \\
\hline $\mathrm{SC}$ & 0.46 & 0.42 & 1.64 & 0.45 & 30448 & 95.7 & 6248 & 0.774 & 0.17 & 0.88 \\
\hline SE & 0.56 & 0.48 & 0.65 & 0.57 & 15167 & 21.9 & 2068 & 0.665 & 0.19 & 0.46 \\
\hline SP & 0.53 & 0.49 & 2.23 & 1.48 & 35264 & 248.2 & 41262 & 0.783 & 0.12 & 0.91 \\
\hline $\mathrm{TO}$ & 0.55 & 0.51 & 0.35 & 0.33 & 15865 & 277.7 & 1383 & 0.699 & 0.25 & 0.31 \\
\hline BR & 0.56 & 0.50 & 1.24 & 0.69 & 21200 & $*$ & $* *$ & 0.70 & 0.18 & 0.61 \\
\hline
\end{tabular}

Source: Area (1.000K 2 ), Population (Pop, 1000 people), Progressivity (Prog.), HID (Human Index Development), Liquid Debt (DL, proportion of Total Revenue), ICMS (proportion of Total Revenue), HDI and Population are for 2010, and the other variables for 2014. Acre (AC); Alagoas (AL); Amazonas (AM); Amapá (AP); Bahia (BA); Ceará (CE); Distrito Federal-Brasília (DF); Espírito Santo (ES); Goiás (GO); Maranhão (MA); Minas Gerais (MG); Mato Grosso do Sul (MS); Mato Grosso (MT); Pará (PA); Paraíba (PB); Piauí (PI); Paraná (PR); Rio de Janeiro (RJ); Rio Grande do Norte (RN); Rio Grande do Sul (RS); Santa Catarina (SC); Sergipe (SE); São Paulo (SP); Tocantins (TO) e; Brasil (BR). * 8516.7; ** 190746. 
While, for instance, São Paulo e Distrito Federal present socioeconomic indicators similar to those of high-income, with a significant participation of the industrial and service sectors, others, such as Piauí e Maranhão, show numbers of low-income economies due to their low diversification and relevant participation of low productivity agriculture. Likewise, there are states with almost complete fiscal autonomy, such as São Paulo and Mato Grosso do Sul, and those with high dependence on central government transfers such as Acre e Amapá. This high dependence is related to the lack of a local economic base capable of generating the necessary tax revenue. These differences reflect the large regional economic disparities in Brazil. Due to the country's industrialization pattern throughout the $20^{\text {th }}$ century, the federative units located in the Northeast and North regions have lower levels of economic development than the units located in the Southeast and South regions.

Between 2004 and 2014, improvements were observed in the income distribution indicators of the states and in their fiscal situations, measured by the debt ratio in proportion to net revenue. Also, there is an increase in the progressivity index of most states, measured by the relation between direct and indirect taxes, similar to the methods of González and Martner (2012).

Another measure of fiscal efficiency is the tax autonomy index, measured as the ratio between the main state tax, denominated Tax on the Circulation of Goods and Services (ICMS, as per its initials in Portuguese), and the total net revenue of each state. Considering the average index of the 27 units of the federation, the index increased from 0.36 to 0.61 between 2004 and 2014, meaning that such subnational units were less dependent on transfers from the federal government to cover their expenses. Thus, during the period analyzed in the present study, the states were expanding their capacity for fiscal execution and, therefore, intervention on the final distribution of income among families.

\section{DATA AND EMPIRICAL STRATEGY}

\section{III.1. Data}

The data related to the fiscal variables used in this research for the Brazilian federal units are obtained from the National Treasury Secretary in the accounting information of the states in the budget execution item ${ }^{2}$. The data are in Reais (R\$)

2 In addition to the states and the Federal District, information on the municipalities are also available and can be accessed through the link: <http://www.tesouro.fazenda.gov.br/contas-anuais $>$. 
and were deflated by the National Wide Consumer Price Index (Índice Nacional de Preços ao Consumidor Amplo, or IPCA, as per its initials in Portuguese) at December 2014 prices. All variables were calculated in terms of per capita, considering the respective populations of each federative unit. Table A.1 in appendix summarizes the descriptive statistics.

The Gini index is the measure of inequality and the dependent variable utilized in the empirical analyses. The Gini index shows a downward direction, decreasing from 0.56 in 2004 to 0.50 in $2014^{3}$. Evidence from several studies suggests that this reduction ${ }^{4}$ in the inequality of income distribution is associated with programs that target income transfers at poor households, especially the Bolsa Familia Program (PBF, as per its initials in Portuguese) (Góes and Karpowicz, 2017; Lustig et al., 2013; Soares et al., 2009, 2010)5. Other factors also contributed to this reduction, such as the real increase in the minimum wage, the increase in formalization in the labor market, and the improvement in workers' educational level (Gonzáles and Martner, 2012).

Public expenditures aimed at improving the living conditions of the population are strong candidates for the reduction in income inequality. If directly, by public cash transfer programs, it currently raise the disposable income of the beneficiary individuals; if indirectly, through offering services in education and health care, the public expenses enable its beneficiaries to obtain higher future income. Analyzing the behavior of these expenditures - specifically education, health services, social assistance and social security - it is possible to deduce a negative relation with the measure of inequality. As shown in Graph 1, expenditures of the federative units in these areas, which as a whole can be termed social expenditure, increased in real terms by $91 \%$ between 2004 and 2014. This increase corresponds to an average annual growth rate of $7 \%$. Together, the expenses in these areas accounted for almost $28 \%$ of the total expenditure of the Brazilian federative units.

3 The Gini indexes are from the National Household Sample Survey/Brazilian Institute of Geography and Statistics (PNAD/IBGE, as per its initials in Portuguese).

4 Góes and Karpowicz (2017) stated that, although there was a reduction in the Gini index for Brazil from 0.54 in 2004 to 0.49 in 2014, inequality is still considered high. Based on data from the PNAD $/ 2014$, the authors indicated that $40 \%$ of the labour income of all Brazilian families is concentrated in $10 \%$ of the wealthiest population, and that the wealthiest $1 \%$ receives approximately $12 \%$, and $0.1 \%$ of the wealthiest population receives approximately $2.5 \%$.

5 Soares et al. (2010) investigated how the PBF contributed to the reduction in inequality in income distribution and poverty in Brazil between 1999 and 2009 and its potential for future contribution. These authors affirmed that the transfer of income due to the PBF was responsible for $15 \%$ of the decrease in the Gini coefficient during that period. 
Moreover, following the expenses in domestic debt services, they were the ones presenting a higher proportion of expenses.

When considering individual evolution, social security expenses presented a higher rate of growth (157\%) than others during the same period. As a proportion of total expenditure, these expenses incorporated an increase of five percentage points between 2004 and 2014. Santos et al. (2017) argued that the rise in security spending is related to real minimum wage gain of approximately $50 \%$ between 2006 and 2015. And with the fact that in several states of the federation, this real increase in wages was passed on to active servants and, on account of legislation, to retired servants. Besides that there was an expansion in the number of inactive servers around of $38 \%$ during the same period.

Graph 1. Aggregate social expenditures of Brazilian states, 2004-2014 (billions of R\$)

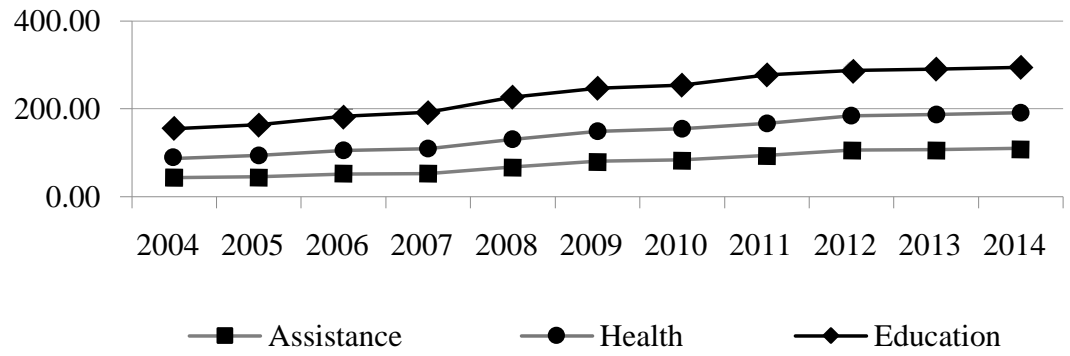

Source: prepared by the authors on the basis of official data from the National Treasury. Note: Data deflated by IPCA at December 2014 prices.

Educational expenses of the Brazilian states grew by $86 \%$, and expenses in health services grew by $52 \%$ in the period under analysis. As a proportion of total expenditures, these expenses presented an average annual participation of $16.13 \%$ of the total expenditure over the full period under analysis. Nevertheless, when comparing the final year to the initial year, there was a reduction of $1.79 \%$. Health spending, in turn, showed a growth of almost one percentage point from 2004 to 2014. In part, this result is associated with the promulgation of Constitutional Amendment No. 29, of 2000, which enabled the growth of contributions from states and municipalities to health services (Benício et al., 2015). 
As for the analysis of other fiscal variables, total revenues increased by $87 \%$ between 2004 and 2014, and total expenditures increased by $71 \%$ in real terms, representing an annual average variation of $6.86 \%$ and $5.89 \%$, respectively, while the annual average variation in the Brazilian GDP was 3.72\% over the same period. But the increase in total revenues occurred without changing a tax structure heavily based on indirect taxes, especially consumption taxes, such as the ICMS tax highlighted in section III. As Warren (2008) showed from extensive review studies, consumption taxes have a significant regressive impact on the distribution of disposable income. In Brazil, the largest share of indirect taxes falls on the consumption of goods and services that make up a larger part of the budgets of poorer than richer households. Specifically, there was an increase both in the tax burden and in public expenditures in relation to GDP over the period analyzed without switching the regressive tax structure.

The current revenues (including financial revenues), which account for almost all revenues, reduced their share of total revenue by more than five percentage points between 2004 and 2014. Consequently, capital revenues have become a larger share of revenue, registering a growth of over four percentage points over the full period. In terms of its annual performance, there were decreases of $38.72 \%$ in 2007 , of $33.33 \%$ in 2011 and of $6.13 \%$ in 2014 ; the average growth rate was $27.52 \%$ over the full period. For the years registering growth in capital revenues, 2008, 2009 and 2012 are highlighted, which showed values well above the average: $56.19 \%, 99.19 \%$ and $137.10 \%$, respectively.

Current expenditures accounted for an average of $87.28 \%$ of total expenditures over the full period, with emphasis on personnel expenses, which represented an average of $42 \%$ in the period. In real terms, expenditure on personnel and social charges increased more than $95 \%$ between 2004 and 2014, an average of 7.34\% per year. This result is associated with the significant real wage increases that state public administrations have granted both to active and inactive servers.

Capital expenditure, in turn, represents approximately $13 \%$ of total expenditures, and approximately half of this number is investments. While the broad category of capital expenditure presented an average annual growth rate of $8.74 \%$, investment expenditure grew by an average of $12.32 \%$ per year over the same period. Comparing 2014 with 2004, these growth rates were $110 \%$ and $158 \%$, respectively. 


\section{III.2. Econometric Model}

To identify the impact of fiscal policy on inequality, we adopt the following equation as a base:

$$
Y_{i t}=\alpha Y_{i t-1}+\beta R T_{i t}+\eta D T_{i t}+\mu_{i}+e_{i t}
$$

where $Y_{i t}$ is the measure of income inequality for the 27 Brazilian states $i$ in period $t, Y_{i t-1}$ is the dependent variable lagged over a period, $R T$ is the total revenue, $D T$ is the total expenditure, $\mu$ is an unobservable effect, and $e_{i t}$ is the error term.

To identify which revenues and areas of public spending influence income inequality, we expand model (1) as follows:

$$
Y_{i t}=\alpha Y_{i t-1}+\emptyset_{1} R C_{i t}+\emptyset_{2} R K_{i t}++\mu_{i}+e_{i t}
$$

where $R C_{i t}$ is the current revenue, $R K_{i t}$ is the capital revenue, and $E_{J i t}$ is the set of the seven expenditure groups: social assistance and social security, education and culture, judiciary, infrastructure, debt service, health services, and others.

We use a dynamic ${ }^{6}$ panel System Generalized Method of Moment (GMM) approach to estimate equations (1) and (2). This estimator, proposed by Arellano and Bover (1995) and Blundell and Bond (1998), allows for an unbiased estimate of all variables and is appropriate in addressing situations in which independent variables are not strictly exogenous, meaning they are correlated with past and possibly current realizations of the error (Roodman, 2009).

The potential origin of endogeneity is the omitted variables, which are present in the error term and are correlated with the lagged dependent variable, included in the dynamic model. Other potential sources of endogeneity that are a

6 The dynamics of the model is usually undertaken by including a lag of the dependent variable as a right hand side variable. Moreover, even when the coefficient of lagged dependent variable is not the focus of interest, allowing for dynamics in the underlying process may be crucial for recovering consistent estimates of other parameters (Bond, 2002).

7 The analyses performed by Blundell and Bond (1998) and Blundell et al. (2001) using the Monte Carlo method provide evidence that, in the presence of highly persistent series, the GMM system is more robust than other dynamic panel techniques. In addition, the study performed by Soto (2009) using Monte Carlo simulations for several standard estimators in panel analysis, when $\mathrm{N}$ (number of individuals) is small, concludes that the GMM system estimator generates the result with the least bias, revealing it as the most appropriate method. 
concern in this empirical analysis are the time-invariant unobservable heterogeneity (unobservable difference between Brazilian states as culture, structural conditions, institutional level, that are not captured by available and observable data and, consequently are related to omitted variables) and, simultaneity (when two variables simultaneously affect each other). Then, the endogeneity problem is related to the fact that we cannot control unobserved state factors that could influence the income inequality and, that changes in revenue and expenditure levels affect the inequality measure and vice versa.

The GMM method is useful in trying to address the endogeneity problem as it uses a set of instruments, contained within the panel itself, for potentially endogenous regressors, removing the need for external instruments. In other words, using second and deeper lags of potentially endogenous variables (and their differences) as instruments makes these variables not correlated with the error term. For example, the past values of expenditure can be used as an instrument for current expenditure.

The validity of the GMM system estimator is conditional upon the exogeneity of the instruments. To verify this exogeneity, we apply two key tests. The first one is the Hansen ${ }^{8}$ test of over-identification that yields a J-statistic, which is distributed $\chi^{2}$ under the null hypothesis that all instruments are valid. The rejection of the null hypothesis implies that some of the instruments are not valid. The second one is the difference-in-Hansen test (or C test) that inspects the exogeneity of a particular subset of instruments 9 .

The GMM method is also subject to the absence of second-order autocorrelation of the errors; therefore, we apply the Arellano-Bond test for serial correlation in the first-differenced residuals, under the null hypothesis of no serial correlation. The implementation of this empirical strategy is found in the next section.

8 The Hansen J statistic, which does not require homoscedasticity for testing over-identification, instead of the Sargan statistic, which requires homoscedasticity.

9 However, many instruments may generate a possible over-identification of the endogenous variables, not allowing adequate treatment of endogeneity and generating biased estimates, and may also impede the power of the Hansen test itself. To work around this problem, we collapse the instrument matrix, which specifies creating one instrument for each variable and lag distance, rather than one for each time period, variable, and lag distance (Wintoki et al., 2012). 


\section{BENCHMARK RESULTS}

The idea is to verify the impact of fiscal policy - for revenue and expenditure variables ${ }^{10}$ - on income inequality measured by the Gini index. We proceed from the aggregate to the disaggregate level. That is, first we ascertain the impact of total revenues and expenditures on inequality, and these two broad categories are then disaggregated, but with a focus on expenditures. This strategy means that it is possible to estimate both the general impact of fiscal policy on inequality and the marginal contribution of some fiscal components, whether of revenue or expenditure.

Table 2 shows the outcomes of the dynamic regressions and the diagnostic tests, which are all supportive of the estimation choices made. The Arellano-Bond test for first- and second-order serial correlation (AR1 and AR2) suggests that, for most specifications, the former is present but the latter is not, which is coherent with our underlying assumptions, and the p-values for the Hansen tests are above the minimum of 0.25 , as recommended by Roodman (2009). Thus, the test of overidentification cannot reject the null hypothesis that all instruments are valid, and the difference-in-Hansen p-values imply that we cannot reject the hypothesis that the subset of instruments (GMM or IV) used is truly exogenous. All the explanatory variables are treated as potentially endogenous, due to the instruments being lagged in 2 or 3 years.

In all the columns of Table 2 , the lagged dependent variable is statistically significant, which supports our preference for dynamic models as the main econometric tool of this study. This variable captures the past (or history) of the whole model and not merely the past of the dependent variable (Greene, 2012; Piper, 2014).

The lagged Gini coefficient obtained is approximately 1, significant and positive, meaning that the impact of the fiscal variables on income inequality is more historic than contemporaneous. Other studies that use the GMM system also find a similar result for the lagged dependent variable, although with differences in the fiscal variables used, period length and the groups investigated (Woo et al., 2013; Azevedo et al., 2014) ${ }^{11}$.

10 In this way, all the elements of the budgetary restriction of the federative units are considered.

11 Woo et al. (2013) found a large (more than 1) and significant positive influence of lagged Gini on current Gini. In Azevedo et al. (2014), the coefficient on the lagged dependent variable is approximately 0.60 . 
Table 2. The Impact of Fiscal Policy on Inequality (System GMM Results)

\begin{tabular}{|c|c|c|c|}
\hline Dependent Variable: Gini & A & $\mathrm{B}$ & $\mathrm{C}$ \\
\hline Gini (t-1) & $0.84^{* * *}$ & $0.99^{* * *}$ & $0.99^{* * *}$ \\
\hline Total Revenue & $0.11^{*}$ & & \\
\hline Total Expenditure & $-0.12^{*}$ & & \\
\hline Current Revenue & & -0.05 & -0.13 \\
\hline Capital Revenue & & $0.47^{* * *}$ & $0.24^{*}$ \\
\hline Social Security Exp. & & $-0.20^{* * *}$ & $-0.16^{* *}$ \\
\hline Education Exp. & & 0.40 & 0.13 \\
\hline Judiciary Exp. & & -0.37 & -0.22 \\
\hline Infrastructure Exp. & & -0.51 & $-0.41^{* *}$ \\
\hline Debt Exp. & & $0.21^{*}$ & $0.28^{*}$ \\
\hline Health Exp. & & & 0.50 \\
\hline Other Exp. & & & 0.36 \\
\hline Instruments & 19 & 26 & 30 \\
\hline Obs. & 270 & 270 & 270 \\
\hline $\mathrm{AR}(1)$ & 0.00 & 0.00 & 0.00 \\
\hline $\mathrm{AR}(2)$ & 0.10 & 0.34 & 0.19 \\
\hline Hansen test & 0.21 & 0.56 & 0.81 \\
\hline Dif. GMM & 0.34 & 0.70 & 0.92 \\
\hline Dif. IV & - & 0.66 & 0.93 \\
\hline
\end{tabular}

Source: prepared by the authors.

Notes: data in 10000 Reais per capita; The Dif. GMM and Dif. IV refer to difference-in-Hansen test of exogeneity. The values reported for the autocorrelation and Hansen tests are p-values. All estimations include orthogonal deviations, two-step and collapsed. Bias-corrected heteroscedasticity-robust standard errors driven by Windmeijer (2005). ${ }^{* * *},{ }^{* *}$ and ${ }^{*}$ indicate statistical significance at the $1 \%, 5 \%$ and $10 \%$ levels, respectively. 
Column A shows that total revenue and total expenditures are significant and that, in the Brazilian states, between 2004 and 2014, the increase in total revenue generated an increase in inequality, while an increase in total expenditures generated a decrease in the inequality of income distribution.

As already indicated, the negative effect of revenue on the inequality of income distribution is probably related to the fact that the Brazilian tax system is concentrated on indirect taxes. We further discuss this aspect in the section on robustness evaluations, where we add an index of progressivity as a control variable. On the other hand, the positive effect of expenditure on the Gini index is possible in capturing the influence of social expenditure, which, as the literature shows, has a priori significant potential to reduce inequality (Warren, 2008; Martinez-Vazquez et al., 2014).

Columns $\mathrm{B}$ and $\mathrm{C}$ disaggregate the total revenue into current and capital revenues and the total expenditure in some categories. In regression $\mathrm{B}$, the variable on expenditure on assistance and social security is significant and negative, which suggests a relation with the preliminary analyses in section III.1, in which an increase in social spending contributes to the reduction of inequality in the Brazilian states.

Capital revenues are positive and significant at the level of $1 \%$ in regressions $\mathrm{B}$ and $\mathrm{C}$, indicating that an increase in these revenues generates an increase in the inequality of income distribution. As noted in the section on descriptive analyses, capital revenue increased during the period investigated. This increase means the expansion, over the analyzed period, of the use of credit operations, public indebtedness, by the Brazilian states as a source of revenue to support their expenditures.

Another variable that contributes to worsening inequality is debt expenditure, which is significant at the level of $10 \%$. A rise of 10,000 Reais per capita, with expenses related to refinancing and public debt service, raises the Gini index by 0.211 , and a rise of the same amount of expenses in social assistance and social security reduces the inequality by 0.20 . In this sense, there is no net effect.

In the final regression $\mathrm{C}$, which includes seven categories of expenditure, the social assistance and social security variable remains significant and with a negative sign. The debt expenditure again shows a positive sign and is significant; thus, this negative effect overcomes the positive effect of the former, and the variable infrastructure expenditure maintains the negative signal, but now with statistical significance at $10 \%$. 
Overall, when evaluating the structures of revenues and expenditures of the 27 federative units of Brazil for the period from 2004 to 2014, we find that results coinciding with those observed in other studies confirm the literature review. For example, our econometric test indicated that the so-called social expenditures contributed to the equalization of income, a result found in several international studies, such as those examining Argentina, Chile and Uruguay. The econometric test also indicated that an increase in revenue increased income inequality, which was expected when considering the important role played by indirect taxes in the fiscal revenue of the federal units of Brazil (see the cases of Colombia and Peru, for example). Even the nonsignificant signal for education expenditures can be explained by two causes: 1) in Brazil, states are responsible for the provision of secondary education and, in some of them, also for the provision of higher education. As shown in other studies (Chile), spending at these levels of education seems to have no or little effect on income distribution; and 2) most of the increase in education expenditures was directed to the salary increase of public employees working in the sector.

Nevertheless, by separating public expenditures from those directed to paying the debts of the states, we find that these increase the Gini index. This result calls for attention, and we know of no specific studies in Latin America that have demonstrated this relation. However, in a cross-country panel data involving 120 economies, Salti (2015) found evidence similar to that presented in our study, explaining this result in terms of those parcels with higher income holding proportionally more public debt securities and thus receiving more interest transfers.

Thus, benchmark results suggest that there are fiscal variables that significantly affect inequality in income distribution in the Brazilian states and contribute to its reduction, such as total expenditure, expenditures with social assistance and social security, and infrastructure. In addition, there are also fiscal variables, such as total and capital revenue and debt expenditure that increase inequality. We recognize, however, that our findings only point to evidence of correlation between some types of revenues and fiscal expenditures with the measure of income inequality, without necessarily determining the causal relationship between such variables.

\section{ROBUSTNESS EVALUATION}

Though the diagnostic tests, reported at the bottom of Table 2, indicate that the models perform well, certifying these results, we decided to perform a rigorous robustness evaluation in three different steps. First, we employ another measure of 
income inequality, the Theil index, which is more sensitive to changes in the upper tail of income distribution, while the Gini index, the most widely used inequality measure, is more sensitive to changes in shares in the middle of the distribution (Hoffman, 1998; Bastagli et al., 2012). Second, we include additional control variables to the base model. Third, we adopt a different methodology (static models ${ }^{12}$ ) to run the benchmark regressions presented in Table 2 .

The results of these three steps are largely in line with those in the previous section, with the majority of the variables of interest being statistically significant and showing the same signs ${ }^{13}$. Specifically, Table 3 presents the results that we obtained from estimating equations (1) and (2) when other control variables were included in the analysis along with the tax and expenditure variables. Following Martinez-Vazquez et al. (2014), we consider as control variables those that have been consistently found to play a significant role in explaining income inequality in the literature ${ }^{14}$.

Table 3. Adding Controls in the Benchmark Regressions (System GMM Results)

\begin{tabular}{|c|c|c|c|c|c|}
\hline Dependent Variable: Gini & A & $\mathrm{B}$ & $\mathrm{C}$ & $\mathrm{D}$ & $\mathrm{E}$ \\
\hline Gini (t-1) & $0.58 * * *$ & $0.66^{* * *}$ & $0.63 * * *$ & $0.60 * * *$ & $0.62 * * *$ \\
\hline Gini $(t-2)$ & $0.38 * * *$ & $0.38 * * *$ & $0.36^{* * *}$ & $0.40 * * *$ & $0.35 * * *$ \\
\hline Total Revenue & $0.08 * *$ & $0.01 *$ & & & $0.15^{* *}$ \\
\hline Total Expenditure & $-0.09 * *$ & $-0.11^{*}$ & & & \\
\hline Current Revenue & & & -0.05 & -0.07 & \\
\hline Capital Revenue & & & $0.55 * *$ & $0.53 * * *$ & \\
\hline
\end{tabular}

12 The static models, fixed-effects (FE) and random-effects (RE), cannot provide the entire history of the model, so they are not directly comparable to dynamic models (Wintok et al., 2012).

13 To save space, we display only the results of the second step (additional controls); the others can be provided upon request.

14 Such as GDP per capita, unemployment, education level, progressivity index and economic openness. We measure progressivity using the ratio of direct tax revenue/indirect tax revenue, as González and Martner (2012) did, and the openness using the value of exports plus imports relative to GDP. 


\begin{tabular}{|c|c|c|c|c|c|}
\hline Social Security Exp. & & & $-0.16^{* *}$ & $-0.14 * * *$ & $-0.16^{* * *}$ \\
\hline Education Exp. & & & 0.20 & 0.18 & 0.10 \\
\hline Judiciary Exp. & & & 0.14 & & -0.613 \\
\hline Infrastructure Exp. & & & -0.40 & $-0.33 * *$ & $-0.61 * * *$ \\
\hline Debt Exp. & & & 0.17 & $0.25^{*}$ & -0.25 \\
\hline Health Exp. & & & & & 0.020 \\
\hline GDP pc & -0.00 & & 0.00 & 0.00 & -0.00 \\
\hline Unemployment & 0.20 & & 0.33 & 0.32 & 0.18 \\
\hline Education level & 0.00 & & -0.01 & -0.01 & \\
\hline Progressivity & -0.01 & $-0.12 * *$ & -0.06 & -0.11 & -0.16 \\
\hline Open & 0.05 & -0.08 & 0.15 & 0.09 & 0.16 \\
\hline Obs. & 243 & 243 & 243 & 243 & 243 \\
\hline $\operatorname{AR}(1)$ & 0.006 & 0.008 & 0.003 & 0.003 & 0.011 \\
\hline $\operatorname{AR}(2)$ & 0.753 & 0.531 & 0.554 & 0.587 & 0.816 \\
\hline Hansen test & 0.345 & 0.418 & 0.577 & 0.774 & 0.385 \\
\hline
\end{tabular}

Source: prepared by the authors.

Notes: the fiscal data is in 10000 Reais per capita; The Dif. GMM and Dif. IV refer to difference-inHansen test of exogeneity. The values reported for the autocorrelation and Hansen tests are $p$-values. All estimations include orthogonal deviations, two-step and collapsed. Bias-corrected heteroscedasticity-robust standard errors driven by Windmeijer (2005). ${ }^{* * *},{ }^{* *}$ and ${ }^{*}$ indicate statistical significance at the $1 \%, 5 \%$ and $10 \%$ levels, respectively. 
As expected, the coefficients for total revenue and total expenditure are positive and negative, respectively, and continue to be significant in all specifications. More important for our purposes is that, for the majority of the results in Table 2, when we add new controls, the coefficients continue to be significant and their signals do not change.

Notably, however, the results in Table 3 show that the only extra control variable that is statistically significant is the progressivity index, with a positive effect on inequality. Thus, the Brazilian state with a more progressive tax structure may have a lesser inequality income distribution. This result is in line with the literature (Duncan and Sabirianova Peter, 2008; Martinez-Vazquez et al., 2014).

It is noteworthy that among the variables of the social expenditure set, throughout various robustness evaluations (additional controls, different measure of inequality and alternative methodology), the variable referring to social assistance and social security expenditures has a positive impact on inequality in the income distribution of the Brazilian states ${ }^{15}$. Santos et al. (2017) also obtained that these expenditures are important for reducing the inequality of income in the Brazilian states. Similarly, González and Martner (2012) found that, for Latin American countries, by separating social spending from public expenditure on education, an increase in the former can explain the improvements in the Gini coefficient.

In summary, based on the evidence presented in this study, we can affirm that fiscal policy, more specifically the structure of expenditures and taxes of the states, is important for reducing inequality in income distribution, which is in line with the literature (Chu et al., 2004; Afonso et al., 2010; Bastagli et al., 2012; Azevedo et al., 2014; Lustig, 2016). However, those responsible for conducting the fiscal policies of the Brazilian states must be aware that an increase in special charges worsens inequality, and this is strongly shown in the results of this study.

\section{FINAL CONSIDERATIONS}

The objective of this study was to investigate the potential impact of fiscal policy on income inequality of the Brazilian states with special attention to public

15 In other specifications (the results of which were not reported), for example, when only this variable and total revenue were included or when all expenditure groups, except for health services, were inserted with the disaggregated revenues, this component of the social area has always appeared as significant and with a negative sign. 
spending, which was divided into seven groups. The period from 2004 to 2014 was analyzed using the System GMM method.

The results indicated that total expenditures, social assistance and security expenditures, and infrastructure expenditures are related to reducing income inequality, which, measured by the Gini index, decreased from 0.56 to 0.50 in the analyzed period. In its turn, total and capital revenues, expenses with special charges, accentuate inequality in income distribution. Thus, it can be said that the governments are giving with one hand and taking away with the other.

In general, we found evidence that the spending policies of the Brazilian states may affect their respective income inequality indexes. That is, the states and the federal district have the room to implement pro-equity (or anti-equity) fiscal policies, considering only how these federative units decide to allocate their revenues in different types of expenditures. In turn, given the Brazilian regressive tax structure, we observed that increases in tax revenues contribute to the rise of inequality in income distribution.

In view of the evidence presented here, we emphasize the need to promote a tax reform capable of establishing a more progressive structure in the country. This reform, coupled with a public spending structure that privileges those with a greater capacity to raise equity and higher efficiency and effectiveness in spending on education and public health service, could provide Brazil with a fiscal policy effectively able to collaborate in reducing inequality of income.

Considering the current tax structure, the net effects of expanding, for example, social spending by means of a higher tax collection, may not be positive for the objective of reducing income disparities. Therefore, discussion of how to determine and qualify social spending levels in Brazil, which are necessary to combat poverty and reduce social and income inequalities, is directly related to the issue of the revision of the overall progressivity of the tax-benefit system.

One distinct finding in our work has been the significant reductive impact on income inequality of state investment spending. How can this impact be explained? One hypothesis is that such investments generally involved civil construction projects, a highly demanding sector of unskilled labor in Brazil. Thus, the state governments, in increasing their spending on investments, also increased the demand for the production factor of low-qualification work. We will test this hypothesis in future research. If this hypothesis is found valid, there is a possibility that the improvement in income distribution observed during the study period was not a 
structural change and could be reversed by a decrease in these expenses with the economic and fiscal crisis observed in Brazil beginning in 2015.

\section{APPENDIX A}

Table A.1. Descriptive statistics

\begin{tabular}{|c|c|c|c|c|c|}
\hline Variables & $\mathrm{n}$ & $\min$ & $\max$ & mean & $\mathrm{sd}$ \\
\hline Gini & 297 & 0.42 & 0.63 & 0.53 & 0.04 \\
\hline Theil & 297 & 0.33 & 1.31 & 0.58 & 0.11 \\
\hline Total Revenue & 297 & 172.93 & 92293.91 & 4380.74 & 7958.67 \\
\hline Total Expenditure & 297 & 159.72 & 91295.66 & 4148.81 & 7565.07 \\
\hline Current Revenue & 297 & 184.28 & 81499.49 & 4297.31 & 7125.74 \\
\hline Capital Revenue & 297 & 2.71 & 2082.30 & 210.56 & 284.21 \\
\hline Social Security Exp. & 297 & 12.94 & 12308.81 & 514.35 & 1185.78 \\
\hline Education Exp. & 297 & 22.21 & 17821.93 & 685.37 & 1371.21 \\
\hline Judiciary Exp. & 297 & 0.00 & 5341.34 & 271.40 & 457.94 \\
\hline Infrastructure Exp. & 297 & 9.28 & 8019.27 & 351.12 & 649.27 \\
\hline Debt Exp. & 297 & 9.07 & 25346.24 & 858.82 & 2174.40 \\
\hline Health Exp. & 297 & 21.55 & 9186.24 & 508.44 & 819.91 \\
\hline Other Exp & 297 & 31.94 & 7678.57 & 629.86 & 716.35 \\
\hline Open & 297 & 0.00 & 0.32 & 0.10 & 0.07 \\
\hline GDP pc & 297 & 4763.11 & 60156.92 & 17485.70 & 9920.58 \\
\hline
\end{tabular}




\begin{tabular}{lccccc} 
Unemployment & 297 & 0.03 & 0.17 & 0.09 & 0.03 \\
\hline $\begin{array}{l}\text { Education level (years) } \\
\text { Progressivity Index }\end{array}$ & 297 & 4.18 & 10.08 & 6.75 & 1.15 \\
\hdashline & 297 & 0.07 & 0.52 & 0.15 & 0.07 \\
\hline
\end{tabular}

Source: prepared by the authors. The fiscal data is in Reais per capita and are from the National Treasury; GDP are from the Brazilian Institute of Geography and Statistics (IBGE, as per its initials in Portuguese) in the Regional Accounts of Brazil; Education level, unemployment and open are from Institute of Applied Economic Research (IPEA, as per its initials in Portuguese).

\section{REFERENCES}

Afonso, A., Schuknecht, L., \& Tanzi, V. (2010). Income distribution determinants and public spending efficiency, The Journal of Economic Inequality 8 (3), 367-389.

Arellano, M., \& Bover, O. (1995). Another look at the Instrumental Variable Estimation of Error-Components Models. Journal of Econometrics, 68 (1), 29-51.

Azevedo, J. P., David, A. C., Bastos, F. R., \& Pineda, E. (2014). Fiscal adjustment and income inequality: Sub-national evidence from Brazil. The World Bank, Working Paper No. 6945. Washington, DC.

Ball, L. M., Furceri, D., Leigh, M. D., \& Loungani, M. P. (2013). The distributional effects of fiscal consolidation. International Monetary Fund, Working Paper No. 13/151 Washington, DC.

Bartolini, D., Stossberg, S. \& Blochliger, H. (2016). Fiscal decentralization and regional disparities. OECD, Working Paper No. 1330. Recuperado de https://doi.org/10.1787/5jlpq7v3j237-en

Bastagli, F., Coady, D., \& Gupta, S. (2012). Income inequality and fiscal policy. International Monetary Fund, Working Paper No. 12/08R. Washington, DC.

Benício, A. P., Rodopoulos, F. M. A., \& Bardella, F. P. (2015). Um retrato do gasto público no Brasil: por que se buscar a eficiência. En R. Bouer, F. Rocha, \& F. Rodopoulos (Eds.). Avaliação da Qualidade do Gasto Público e Mensuração da Eficiência (pp. 19-52). Brasília: Secretaria do Tesouro Nacional.

Bértola, L., \& Ocampo, J. A. (2012). The Economic Development of Latin America since Independence. Oxford: Oxford University Press.

Blundell, R., \& Bond, S. (1998). Initial conditions and Moment Restrictions in Dynamic Panel Data Models. Journal of Econometrics, 87 (1), 115-143.

Blundell, R., Bond, S., \& Windmeijer, F. (2001). Estimation in Dynamic Panel Data Models: Improving on the performance of the Standard GMM Estimato. En 
B. H. Baltagi (Ed.). Nonstationary panels, panel cointegration, and dynamic panels (pp. 53-91). Bingley: Emerald Group Publishing Limited.

Bond, S. R. (2002). Dynamic Panel Data Models: a guide to micro data methods and practice. Portuguese Economic Journal, 1 (2), 141-162.

Bucheli, M.; Lustig, N.; Rossi, M. \& Amábile, F. (2013). Social spending, taxes and income redistribution in Uruguay. The World Bank, Policy Research Working Paper No. 6380.

Chu, K. Y., Davoodi, H., \& Gupta, S. (2004). Income distribution and tax and government social-spending policies in developing countries. En G. A. Cornia (Ed.). Inequality, Growth, and Poverty in an Era of Liberalization and Globalization (pp. 249-270). Oxford: Oxford University Press.

Clements, B. J., De Mooij, R. A., Gupta, S., \& Keen, M. (2015). Inequality and Fiscal Policy. Washington, DC: International Monetary Fund.

Clifton, J., Díaz-Fuentes, D., \& Revuelta, J. (2017). Fiscal policy and inequality in Latin America, 1960-2012. En L. Bértola \& J. Williamson (Eds.). Has Latin American Inequality Changed Direction? Looking Over the Long Run (pp. 387-406). Cham: Springer.

Cont W., \& Porto A. (2016). Fiscal policy and income distribution: measurement for Argentina 1995-2010. Review of Economic and Finance, 6 (2), 71-88.

Cornia, G. A. (2014). Inequality trends and their determinants: Latin America over the period 1990-2010. En G. A. Cornia (Ed.). Falling inequality in Latin America: policy changes and lessons (pp. 24-49). Oxford: Oxford University Press.

Deininger, K., \& Squire, L. (1996). A new data set measuring income inequality. World Bank Economic Review, 10, 569-591.

Duncan, D. \& Sabirianova Peter, K. (2008). Tax progressivity and income inequality. Georgia State University Andrew Young School of Policy Studies, Working Paper, No. 08-26.

Góes, C., \& Karpowicz, I. (2017) Inequality in Brazil: A regional perspective. Washington, DC: International Monetary Fund.

Goñi, E., López, J. H. \& Servén, L. (2011). Fiscal redistribution and income inequality in Latin America. World Development, 39 (9), 1558-1569.

González, I., \& Martner, R. (2012). Overcoming the empty box Syndrome. Determinants of income distribution in Latin America. Cepal Review, 108, 7-25.

Greene, W. H. (2012) Econometric analysis. London: Pearson.

Gobetti, S. W. \& Orair, R. O. (2017). Taxation and distribution of income in Brazil: new evidence from personal income tax data. Brazilian Journal of Political Economy, 37 (2), 267-286.

Hoffmann, R. (1998). Distribuição de renda: medidas de desigualdade e pobreza. São Paulo: Editora da Universidade de São Paulo. 
Joumard, I. \& Vélez J. L. (2013). Income inequality and poverty in Colombia. Part 2. The Redistributive Impact of Taxes and Transfers. OECD Working Paper, No. 1037.

Kuznets, S. (1955). Economic growth and income inequality. The American Economic Review, 45 (1), 1-28.

Lustig, N. (2016). Fiscal policy, inequality and the poor in the developing world. WIDER, Working Paper No 164.

Lustig, N., Lopez-Calva, L. F., \& Ortiz-Juarez, E. (2013). Declining inequality in Latin America in the 2000s: The cases of Argentina, Brazil, and Mexico. World Development, 44 (C), 129-141.

Martinez-Aguilar, S., Fuchs, A., Ortiz-Juarez, E., \& Del Carmen G. (2017). The impact of fiscal policy on inequality and poverty in Chile. CEQ Institute, Tulane University, Working Paper No. 46.

Martinez-Vazquez, J., Vulovic, V., \& Moreno Dodson, B. (2014). The impact of tax and expenditures policies on income distribution: evidence from a large panel of countries. Review of Public Economics, 200 (4), 95-130.

Medeiros, M. \& Souza, P. H. G. F. (2015). State transfers, taxes and income inequality in Brazil. Brazilian Political Science Review, 9 (2), 3-29.

Oates, W. (1972). Fiscal Federalism. New York. Harcourt Brace.

Piketty, T. (2014). Capital in the Twenty-First Century. The Belknap Press of Harvard University Press.

Piper, A. T. (2014). The benefits, challenges and insights of a dynamic panel assessment of life satisfaction. MPRA Paper No. 59556, University Library of Munich, Germany.

Roodman, D. (2009). How to do Xtabond2: An introduction to Difference and System GMM. Stata Journal, 9 (1), 86-136.

Rossignolo, D. (2018). Taxes, expenditures, poverty, and income distribution in Argentina. En N. Lustig. Commitment to Equity Handbook. Estimating the Impact of Fiscal Policy on Inequality and Poverty (pp. 516-553). Washington, DC: Brookings Institution Press and CEQ Institute, Tulane University.

Salti, N. (2015). Income inequality and the composition of public debt. Journal of Economic Studies, 42 (5), 821-837.

Santos, C. H. M. D., Almeida, V. L. D., Caldas, L. F., Sá, J. H. B. D., Machado, U. E. N., Martins, F. D. S., \& Brito, A. J. S. D. (2017). A Dinâmica do déficit dos regimes próprios de previdência dos estados brasileiros nos anos 20062015. Carta de Conjuntura, No. 34, 123-153.

Santos, M. P., Cunha, M. S., \& De Brito Gadelha, S. R. (2017). Distribuição de renda e desenvolvimento econômico: Análise da hipótese de Kuznets para os estados brasileiros no período 1992-2010. Revista Brasileira de Estudos Regionais e Urbanos, 11 (2), 251-271. 
Secretary of the National Treasury (2018). Budget Execution of the States, Ministério da Fazenda, Brasilia.

Soares, S., De Souza, P. H. G. F., Osório, R. G., \& Silveira, F. G. (2010). Os impactos do benefício do Programa Bolsa Família sobre a desigualdade e a pobreza. En J. A. Castro, \& L. Modest (Eds.). Bolsa Família 2003-2010: Avanços e Desafios (pp. 25-52). Brasília: IPEA.

Soares, S., Guerreiro Osorio, R., Veras Soares, F., Medeiros, M., \& Zepeda, E. (2009). Conditional cash transfers in Brazil, Chile and Mexico: impacts upon inequality. Estudios Económicos, número extraordinário, 207-224.

Soto, M. (2009). Estimación del sistema GMM con una pequeña muestra. Barcelona Graduate School of Economics, Working Papers No. 395.

Warren, N. (2008). A review of studies on the distributional impact of consumption taxes in OECD countries. OECD Social, Employment and Migration Working Papers, No. 64. Recuperado de http://www.oecd.org/els/soc/40986444. pdf

Windmeijer, F. (2005). A finite sample correction for the variance of linear efficient two-Step GMM estimators. Journal of Econometrics, 126 (1), 25-51.

Wintoki, M. B., Linck, J. S., \& Netter, J. M. (2012). Endogeneity and the dynamics of internal corporate governance. Journal of Financial Economics, 105 (3), 581-606.

Woo, J., Bova, M. E., Kinda, M. T., \& Zhang, M. Y. S. (2013). Distributional consequences of fiscal consolidation and the role of fiscal policy: What do the data say? International Monetary Fund, Working Paper, No. 13/195. Washington, DC.

(C) 2019 por los autores; licencia otorgada a la revista Estudios Económicos. Este artículo es de acceso abierto y distribuido bajo los términos y condiciones de una licencia Atribución-No Comercial 3.0 Unported (CC BY-NC 3.0) de Creative Commons. Para ver una copia de esta licencia, visite http://creativecommons.org/ licenses/by-nc/3.0/ 